\title{
Yu Kilchun's Concept of Reform of the Tax System in the Korean Empire
}

Yang Jinah*

\section{Introduction}

During the Kabo Reform period, the tax system was reformed as a measure to increase the national budget and to stabilize the livelihood of the general public. In the process of collecting taxes, harmful practices, such as excessive demands and exploitation of commoners by local magistrates (suryŏng) and the isŏ class (composed of hyangni, local functionaries, and sŏri, petty clerks), surfaced as problems. Therefore, the government aimed to exclude the isŏ class from the tax collection process and to separate the tasks of tax imposition and collection.

The Korean government during the Kabo Reform period deprived local magistrates and the isŏ class of the right to collect taxes and appointed tax officers to handle tax related matters. However, this endeavor soon foundered due to the opposition of the yangban class and resistance from the iso class, which lost its economic base as a result. ${ }^{1}$ After the so-called

* Ph.D. Candidate, Department of Korean History, Korea University

1 Yi Sangch'an, 1989, “1894-5 nyŏn chibangjedo kaehyŏk ŭi panghyang: hyanghoe ŭi popjehwa sido rŭl chungsimŭro" (Direction of local government system reform during 1894-1895: Focusing on the attempt to legalize hyanghoe), Chindan Hakbo 67, 87-93; Yu Chŏnghyŏn, 1992, “1894-1904 nyŏn chibang chaejŏng chedo ŭi kaehyŏk kwa isŏch'ŭng tonghyang" (The trend of local financial system reform and the isŏ class during 1894-1904), Chindan Hakbo 73, 98-101. 
Ülmi Incident (the assassination of Empress Myŏngsŏng by the Japanese), the tax imposition and collection system was reverted back to the form it

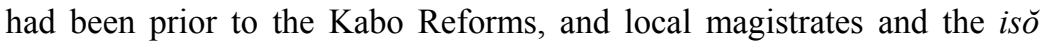
class once again took charge of levying and collecting taxes.

Understanding the is o class's exploitation of commoners in the tax collection process as a problem, $\mathrm{Yu}$ Kilchun pursued tax reform of the Chosŏn government during the Kabo Reforms. In October 1895, as the Minister of Internal Affairs (naemu taesin), he requested the discussion and the majority vote on the "Provision on hyanghoe (district assemblies)" and "Regulations on the management of the Community Compact System (hyangyak)" to systematize hyanghoe and to discuss tax-related matters at hyanghoe. However, with the local magistrates and the isŏ class once again in charge of the tax administration, such an attempt faced limitations. Eventually, Korea became subject to the local administration reform under Japanese colonial rule, with the right to collect taxes still in the hands of the local magistrates and the iso class.

Yu Kilchun's "Semubu (Tax Department)" is a document on taxation created after the failed attempt to revoke the right to collect taxes from local magistrates and the isŏ class during the Kabo Reforms. Existing studies on Yu's concept of the system of public finance have used Söyu kyŏnmun (1895, Observations on travels in the West) and "Chijeǔi”" (1891, Viwes on the land system), "Sejeǔi" (1891, Opinions on the tax system), and "Chaejŏng kaehyŏk" (year unknown, Financial reform), which are essays included in the "Kyŏngje kaehyŏngnon (Theories of economic reform)" section in $Y u$ Kilchun chŏnsŏ 4 (Collected works of $\mathrm{Yu}$ Kilchun). ${ }^{2}$ Using the above sources, studies have noted that $\mathrm{Yu}$ argued for tax reform centered on land tax reform, which was modelled on the land tax reform (J. chiso kaisei) of the Meiji government. Yu's tax reform was considered a "landlord system-based reform," as he attempted to resolve socioeconomic contradictions through tax reform while maintaining the landlord system. ${ }^{3}$ The sources and documents mentioned above were

2 Yu Kilchun chŏnsŏ p'yŏnch'an wiwŏnhoe p'yŏn, 1971, Iljogak. 
also used in studies that analyzed Yu's economic reform ideas as representative of a modern Korean intellectual, as well as studies on the land tax reform theory of the Enlightenment Party (kaehwap'a) in 1894. Most of these studies also concluded that Yu's theory on economic reform was conceived from the perspective of landlords. ${ }^{4}$ Recently, a study revealed that the key to Yu's financial reform theory was the theory of increasing taxes, which was a break from the traditional concept on financial affairs. ${ }^{5}$

Previous studies on Yu's financial reform and tax reform have focused on the period before the Kabo Reform; these studies mainly discussed the national land system and the central tax system, since the only available sources were the ones listed above.

However, considering that $\mathrm{Yu}$ personally participated in the Kabo Reforms as the vice-minister, and later minister, of Internal Affairs and lived in Japan for 12 years afterwards in exile, continuing the discourse only with sources from before the Kabo Reforms has many limitations and leaves much to be desired. In comparison, "Semubu (Tax Department)," a

3 Kim Yongsŏp, 1974, “Kapsin, Kabo kaehyŏkki kaehwap'a ŭi nongŏmnon” (The theory of agriculture of the Enlightenment Party during the Kapsin and Kabo Reforms period), Tongbang Hakji (The Journal of Korean Studies) 15; Kim Yongsŏp, 1988, "Kŭndaehwa kwajŏng esŏŭi nongŏp kaehyŏk ŭi tu panghyang” (Two directions of the agricultural reform in the process of modernizations), Han'guk chabonjuŭi sŏnggyŏk nonjaeng (Debate on the nature of Korean capitalism), Taewangsa.

4 Wang Hyŏnjong, 1997, "19 segi huban chisejedo kaehyŏngnon kwa Kabo kaehyŏk" (Theory of local tax system reform and the Kabo Reform in the late nineteenth century). Han'guk künhyŏndae ŭi minjok munje wa shingukga kŏnsŏl (National problems in modern and contemporary Korea and the founding of a new nation). Kim Yongsŏp Kyosu Chŏngnyŏn Kinyŏm Han'guk Sahangnon Ch'ong Kanhaeng Wiwŏnhoe. Chisik Sanŏpsa; Cho Chŏnghŭi, 2006, "Yu Kilchun ŭi kyŏngje kaehyŏngnon" (Yu Kilchun's theory of economic reform), Han'guk Sasanggwa Munhwa (Korean Thought and Culture) 33.

5 Yang Jinah, 2014, "Kapsin chŏngbyŏn ihu Yu Kilchun ŭi chajŏng kaehyŏngnon" (Yu Kilchun's financial reform theory after the Kapsin Coup). Han'guksa Hakbo 57. 
newly discovered source, was written in the Taehan Empire period, and it addresses tax systems in regions outside of the capital city. Therefore, we expect that this document will provide an important opportunity for improving and enhancing the discourse that began in previous studies.

"Semubu" is one of the documents that was donated by Yu's descendants to the Korea University Museum. Written in mixed Korean and Chinese script, the document is made up of 65 pages and 9,236 characters. With the exception of empty pages, 22 pages consist only of sentences, while 25 pages contain tables. The whole document is equal to the amount of 34 pages of 200-character squared manuscript paper. "Sejeŭi (1891, Opinions on tax reform)," authored by Yu in 1891 on a similar topic, was completely written in Chinese characters and consisted of 3,451

Figure 1. Pages of the draft of Semubu ${ }^{6}$

甲
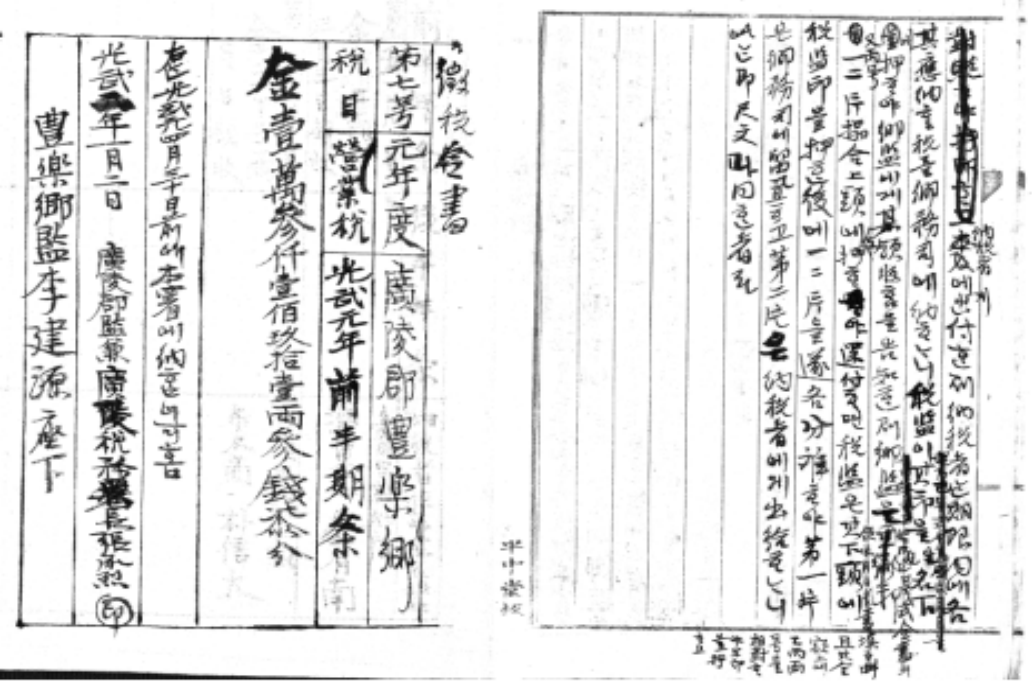

6 The document not only uses words but also tables for explanation. Some of the words have been crossed out, blotted, or rewritten. On the bottom center of the page are Chinese characters for "panjungdangp'an." 
characters on a total of 18 pages, equivalent to 19 pages of 200 -character squared manuscript paper.

"Semubu" was written on ruled "panjungdangp'an" manuscript paper with 12 vertical lines per page. Underlined texts as well as parts that have been blotted out and revised seem to suggest that this is a draft. An analysis of the handwriting suggests that it was written by $\mathrm{Yu}$, as the style of handwriting is the same as that of "Sejeŭi," which had been written in polished Chinese characters without revisions.

Only the word "Semubu (稅務部)" is found on the cover of the document. On the next page, the word “semu (taxation, 稅務)" is written on the first line. As stated on the cover page, it seems appropriate to consider "Semubu" as the title of this document.

Figure 2. Comparison of the handwriting in Semubu and Sejeŭi (1891) ${ }^{7}$

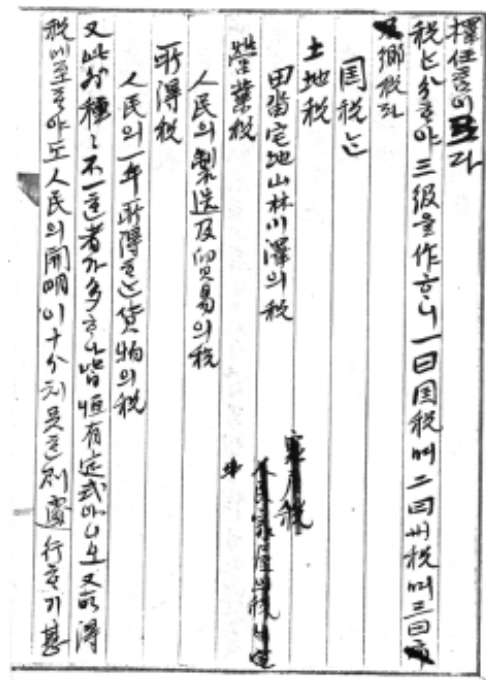

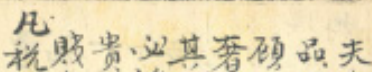

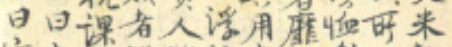

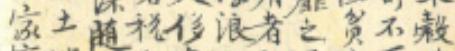
重地修之禀之必品戝可紫 梳税立一之流多在之闹崖 名端滥也后人生者布

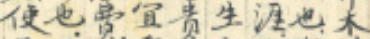

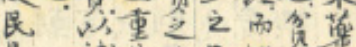
易稂基人日如倍材 知国税又周酒量之

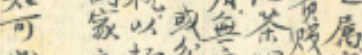

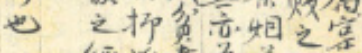
媱浮者多鼻听想

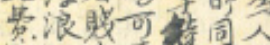

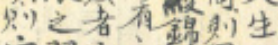

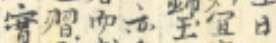
害县求無西䆓用

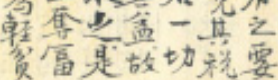

7 The document on the left is "Semubu", and the one on the right is Sejeŭi. 
Figure 3. Cover and the first page of Semubu ${ }^{8}$
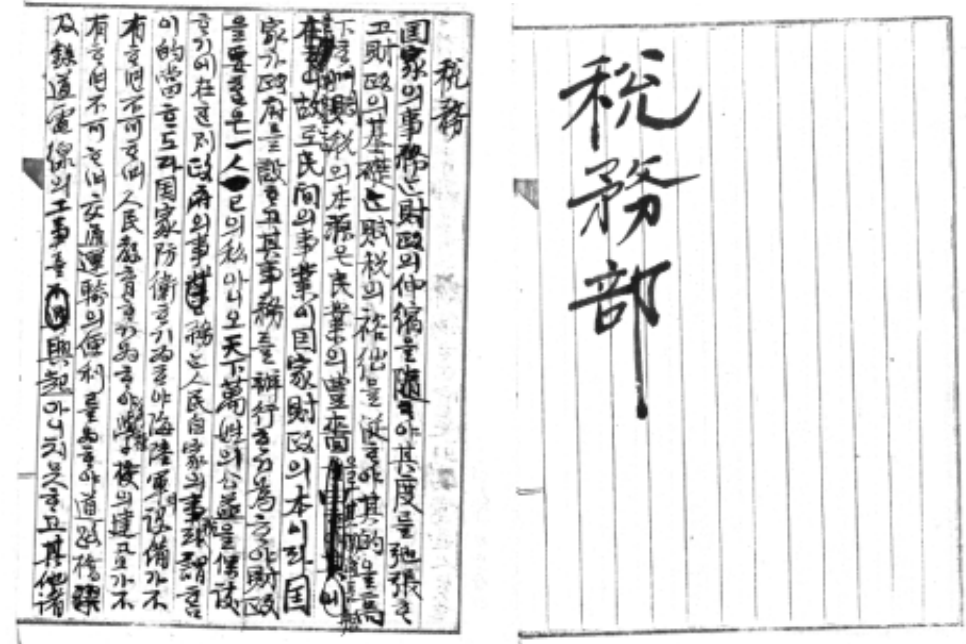

Although the year the document was written is not specified in the work, "the first year of the Kwangmu Era (1897)" and "the second year of the Kwangmu Era (1898)" were written on the sources, such as "tax statement," which appear as examples in "Semubu." Therefore, it seems safe to assume that Yu Kilchun wrote this draft of "Semubu" during Emperor Kojong's reign in the Korean Empire. During the Kwangmu Era (August 1897 to September 1907), Yu was exiled in Japan. With the collapse of the Kim Hongchip cabinet after Emperor Kojong's flight to the Russian Legation in February 1907, Yu left for Japan on exile and was only able to return to Korea after the enthronement of King Sunjong in July 1907. Judging by Yu Kilchun's position on taxation during the Kabo Reforms and the time "Semubu" was written, it seems safe to assume that this paper was written from a perspective, critical of the reactionary trend in the tax system of the Korean Empire.

This study attempts to introduce and analyze the content of the newly

8 The one on the right is the cover page, and left is the first page of the text. 
discovered "Semubu." "Semubu" is largely divided into three parts: one, reasons for the necessity of tax collection; two, types of taxes; and three, tax collection methods. However, instead of delving into each of the three parts in detail, this paper will analyze "Semubu" as a whole, focusing on the characteristic discussions in this document.

\section{Reorganization of Local Administrative Districts}

The "Issue on the establishment of hyanghoe (district assemblies)," which was discussed by the kun'guk kimuch'ŏ (Deliberative Council) on July 12,1894 , is speculated to have been drafted by Yu Kilchun. ${ }^{9}$ The issue called for hyangwŏn, or representatives of each myŏn (township) and members of district assembly, to make collective decisions on the continuation or suspension of township-level activities, such as the enactment of legislation and the rectification of various evils of convention. Previous studies have understood this document as an attempt to prevent the ruling class's exploitation of commoners by involving the local people in politics, ${ }^{10}$ a part of the movement to establish regional assemblies, ${ }^{11}$ or an attempt to institutionalize hyanghoe. ${ }^{12}$ Hyanghoe appears again in the "Regulations on the payment of the land and poll tax (Kyŏlhojŏn

9 Kim T'aeung, 1997, “Kŭndae Chungguk, Ilbon ŭi chibang chach'iron kwa Hanmal ŭi chibang chach'i munje" (The theory of local autonomy in modern China and Japan and the issue of modern autonomy in the late Korean Empire period), Yǒksa Kyoyuk 64, 47, footnote 52.

10 Kim Yongsŏp, 1974, "Kapsin, Kabo kaehyŏkki kaehwap'a ŭi nongŏmnon" (The theory of agriculture of the Enlightenment Party during the Kapsin and Kabo Reforms period). Tongbang Hakji (The Journal of Korean Studies) 15.

11 Chŏng Ch'angryŏl, 1982, "Hanmal pyŏnhyŏk undong ŭi chŏngch'i, kyŏngjejŏk sŏnggyŏk" (The political and economic nature of the reform movement in the late Korean Empire period), Han'guk minjokjuüinon (Theory of Korean nationalism), Ch'angjakgwa Pip'yŏngsa.

12 Kim T'aeung, 1997, “Kŭndae Chungguk." 
pongnap changjŏng)," which grants hyangwŏn the right to taxation, instead of local magistrates and the isŏ class, and specifies that hyangworn should collect and remit land and poll tax (kyŏlhojŏn). This was considered an attempt to increase the national budget by inducing the participation of representatives elected by popular vote in tax administration to reduce harmful practices and remove exploitations of the middlemen. ${ }^{13}$

In April 1895, the Kim Hongchip-Park Yŏnghyo cabinet announced the Legislation on the Office of Internal Revenue and the Office of Taxation (Kwansesa kŭp chingsesŏ kwanje)," "Regulations on Town Tax Agency (Kakŭp puseso changjŏng)," and "Regulations on Income (Suip kyujŏng)" to eliminate the role of hyanghoe in the process of tax collection and established separate organs for tax collection. The Office of Internal Revenue (kwansesa) was installed in each province, and the Office of Taxation (chingsesŏ) was established in each county and district (Tax Agency in each town) to handle tax related matters instead of local magistrates and officials. Compared to the Deliberative Council's measures, this is understood as a reorganization of the tax system that only took into consideration the state's position, incited by Japanese militarists, and dismissed the participation of the people. ${ }^{14}$

Hyanghoe appears again in October 1895, in the "Provision on hyanghoe" and "Regulations on the Management of the Community Compact System" announced by the fourth Kim Hongchip cabinet. These had been brought to the discussion table by Yu Kilchun as the Minister of Internal Affairs. The "Provision on hyanghoe" and "Regulations on the management of the Community Compact System" stated that hyanghoe should consist of rihoe (village assemblies), myŏnhoe (township assemblies), and kunhoe (county assemblies), and that hyanghoe should discuss all affairs within their jurisdiction including taxation and put them to majority vote. It was rather significant that hyanghoe were composed of people regardless of their class. However, as members of hyanghoe only

13 Yi, 1989, “1894-5 nyŏn chibangjedo," 78.

14 Ibid., 83. 
played the role of supporting the government and were restricted from participating in politics, hyanghoe was different from a modern assembly. ${ }^{15}$

$\mathrm{Yu}$ Kilchun maintained similar ideas on hyanghoe during the period Korea was governed by the Deliberative Council and the period when Korea was under the fourth Kim Hongchip cabinet, in that $\mathrm{Yu}$ wanted to systematize hyanghoe and incorporate it into the government administration. "Semubu" also contains Yu's ideas of hyanghoe in the form of chuhoe (state assemblies) and hyanghoe. Yu explained chuhoe as a statelevel assembly, and hyanghoe as a district-level assembly, under the premise that administrative districts were divided into chu and hyang, which were nonexistent at the time.

Administrative divisions in Korea during the Chosŏn dynasty consisted of 8 to (province), 5 pu, 5 taedohobu, 20 mok, 75 tohobu, 77 kun, and 148 hyŏn, which were all under the control of the regional government officials who had been appointed by the central government. Kun and hyŏn (county-level divisions) were divided into smaller units, myŏn and ri. While government officials were not dispatched to oversee myŏn and ri, they were under indirect control of regional government officials as collective units of taxation.

During the Kabo Reforms in May 1895, however, eight to were subdivided into $23 \mathrm{pu}$, and kun and hyon simply became kun, resulting in the administrative divisions of $23 \mathrm{pu}$ and $337 \mathrm{kun}$. This was changed again in August 1896, where $23 \mathrm{pu}$ were redivided into 13 to, each of which consisted of $8 \mathrm{pu}, 1 \mathrm{mok}$, and $332 \mathrm{kun}$. Although the system seems to have reverted back to the time prior to the Kabo Reforms, the fact that 8 to were redivided into 13 and that kun and hyŏn were all simplified into kun

15 Kim T'aeung, 1997, “Kŭndae Chungguk," 50-52; Yi Sangch'an, 1989, “1894-5 nyŏn chibangjedo," 85-86; Yi, 1986, "1906-1910 nyŏn ŭi chibang haengjŏngjedo ŭi pyŏnhwa wa chibang chach'i nonŭi”" (Changes in the local administrative system and a discussion on local autonomy during 1906-1910). Han'guk Hakbo 42, $52-53$. 
suggests that the concept of administrative division during the Kabo Reforms was retained during this time. ${ }^{16}$

According to "Semubu," it seems that Yu Kilchun wanted to reorganize the local government system that had been established in 1896:

...therefore, there is one hyang, called P'ungnak-hyang, which consists of $12 l i$-Kasŏng, Insu, Taejŏng, Chŏnghŭi, Changhang, Piripshin-ri, Samsu, Changch'un, Haechŏn, and P'yŏngch'on. P'ungnak-hyang belongs to Kwangnŭng-gun, which is under the jurisdiction of Hannam-ju (州)... ${ }^{17}$

As seen in the above excerpt, there were $10 \mathrm{ri}$-Kasŏng-ri, Insu, Taejŏng-ri, Chŏnghŭi-ri, Changhang-ri, Piripshin-ri, Samsu-ri, Changch'un-ri, Haechŏn-ri, and P'yŏngch'on-ri-in P'ungnak-hyang, which was under the jurisdiction of Kwangnŭng-gun, which was under the jurisdiction of Hannam-ju. There are no explanations as to the actual location of the areas $\mathrm{Yu}$ proposed in this document, and these are names that were neither in use during Yu Kilchun's lifetime nor in the present day. However, there are clues that hint to where these names came from. Hannam was a different name for Suwon in Kyŏnggi-do. Han-ju was also an old name for Kwangju as well as the name of one of the nine chu and five sogyong (cities) in Shilla. Kwangnŭng was also a different name for Kwangju, Kyŏnggi-do. From this, we can speculate that Kwangnŭng-gun, Hannam$\mathrm{ju}$, is approximately present-day Kwangju in the Kyŏnggi-do area. ${ }^{18}$

16 Yun Chŏngae, 1985, “Hanmal chibangjedo kaehyŏk ŭi yŏn'gu” (Study on the local government system reform in the late Korean Empire period). Yŏksas Hakbo 105, 95.

17 Yu Kilchun, "Semubu” (Tax Department), 9.

18 Han'guk yŏksa chimyŏng sajŏn p'yŏnch'an wiwŏnhoe, 2008, Han'guk yŏksa chimyŏng sajŏn (Dictionary of Place Names in Korean History), Yŏgang Ch'ulp'ansa. Kwangju, Kyŏnggi-do, was the place where Yu Kilchun's family burial ground was located, and it was also where Yu Kilchun spent three years in exile after the Foreign Disturbance of 1866 (Pyŏngin Yangyo). Hanam, Kyŏnggi-do, 
Above all, the most important idea from the excerpt above was that $\mathrm{Yu}$ wanted to reorganize Korea's administrative divisions into chu, kun, hyang, and ri. It was an attempt to change the to (province) into chu (state), unify the kun and hyŏn (county-level administrative divisions) into kun (county), and rename myŏn (town) and ri (village), which were small autonomous administrative units under kun, into hyang (district) and ri.

Figure 4. Administrative Divisions Before and After the Kabo Reform and Yu Kilchun's Concept of Administrative Divisions ${ }^{19}$

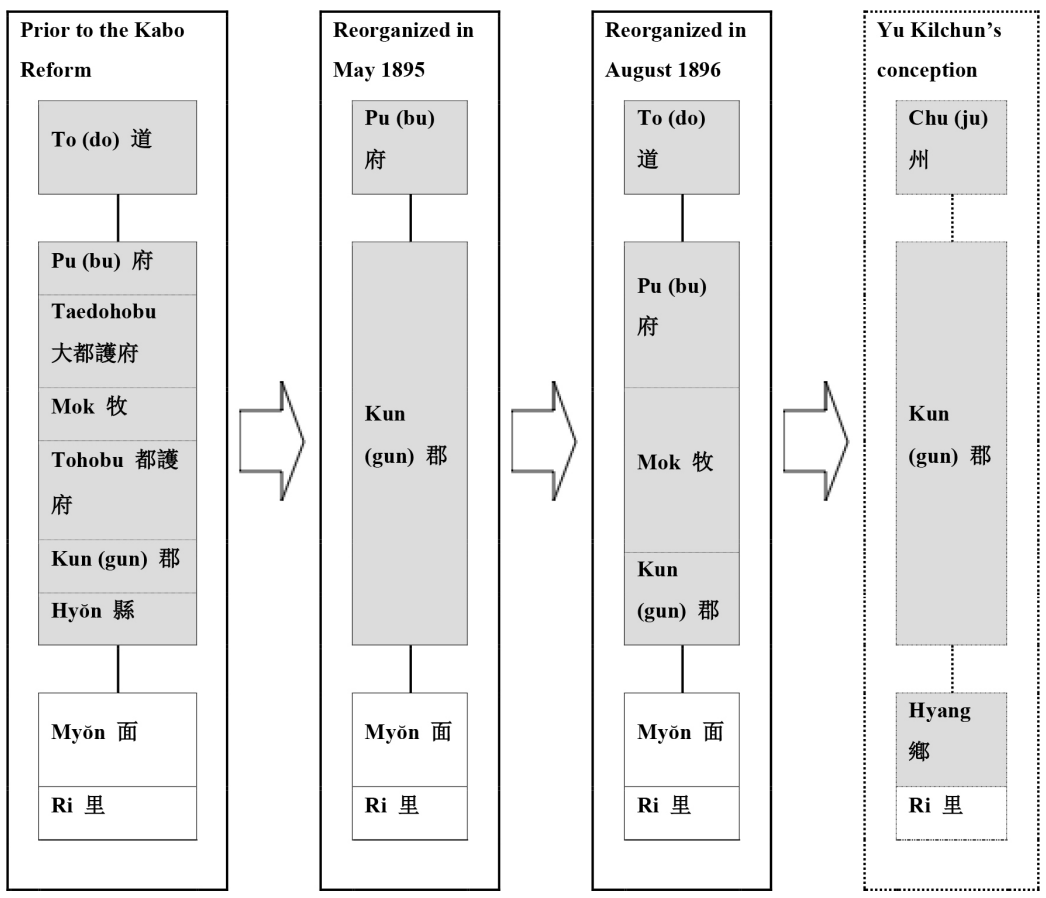

where Yu Kilchun's mother is buried, was part of Kwangju up until 1989.

19 Gray areas refer to government administration units areas included in direct government management system. 
Yu Kilchun's reform idea was in line with the trend of administrative division reform, in terms of redividing broad, provincial-level units and unifying smaller county-level units as kun.

One noteworthy point is that Yu used "chu" as a provincial-level unit of administrative divisions. Chu had been used in Unified Shilla, when the whole country was divided into nine chu and five sogyŏng, and, before that, in ancient China. The Yu Gong (Tribute of $\mathrm{Yu}$ ), a chapter in the Xiashu (Book of the Xia dynasty) section of Shujing, the Book of Documents, records that when Yu ruled China, he had divided the whole nation into nine chu (州 C. zhou)-Yuzhou, Jizhou, Yanzhou Qingzhou, Xuzhou, Yangzhou, Jingzhou, Liangzhou, and Yongzhou. Based on this, China was often referred to as "Ku zhou," meaning nine provinces. During the Han dynasty, all of China was divided into 13 zhou, which was divided into kun (郡 C.jun), which was divided into hyŏn (縣 C. xian).

In Š̆уu kyŏnmun, Yu had already translated the American administrative divisional unit of the "state" and the British administrative division unit of "county" into chu (ju). For instance, Massachusetts, US, was translated as Masa-ju (磨沙州); Lancashire, UK, was Ranjusa-ju (蘭柱沙州). ${ }^{20}$ By applying $c h u$, a unit of local government used in ancient China, to Korea as well as to regions in the US and UK, Yu might have intended to create an equal and uniform administrative divisional system for the world.

Renaming myŏn and $r i$ into hyang and $r i$ is an idea that also appears in Pan'gyesurok (Records of Pan'gye Yu Hyŏngwŏn), written by Yu Hyŏngwŏn (1622-1673). Referring to the ancient Chinese administrative division system, Yu Hyŏngwŏn had also conceived of the hyang-ri system, instead of the existing myŏn-ri system..$^{21}$ Myŏn was not an adminis-

20 Yu Kilchun, 1895, Sо̆у kyŏnmun, Kyosunsa (Kyŏngin Munhwasa, 1969, photographic edition), 3 and 517.

21 O, Yŏnggyo, 1994, "Pan'gye Yu Hyŏngwŏn ŭi chibangjedo kaehyŏngnon yŏn'gu" (Study on Pan'gye Yu Hyŏngwŏn's theory of local government system reform), Kuksagwan Nonch'ong 57. 
trative unit that was under direct government control, but hyang was to be a direct production and governing unit with its territory designated by the central government and ruled by hyangjŏng, an appointed government official.

Yu Hyŏngwŏn's hyang-ri system and Yu Kilchun's hyang-ri system are similar in that both wanted to incorporate low-level administrative divisional units that had not been under direct government control into a governing unit. In the Chosŏn dynasty as well as during the regional government system reform period of 1895 and 1896, myŏn was not considered a governing unit. Only when Korea became a Japanese protectorate, myŏn became recognized as a regional administrative unit and came under direct government supervision in 1917 with Japan's promulgation of the myŏn system. But Yu Kilchun had conceived of a reform of administrative divisional units, where the myŏn becomes a governing unit, even earlier. Since Yu Kilchun mentioned Yu Hyŏngwŏn in Chijeŭi in 1891, it is possible that he consulted Yu Hyŏngwŏn's idea of the hyang-ri system. ${ }^{22}$

\section{Establishment of Local Assemblies and Local Taxes}

$\mathrm{Yu}$ Kilchun argued for the necessity of $c h u$ tax for the operation of a chu and of hyang tax for the operation of hyang, and proposed the implementation of local taxes along with the reorganization of administrative division into the chu-kun-hyang-ri system. Specifically, he proposed that national taxes should consist of land tax, business tax, and income tax; chu taxes should consist of added land tax, added business tax, and

22 In "Chijeŭi," Yu Kilchun criticized the Korean kyŏl-bu system (kyŏlbuje, a Korean system of unit of areal measurements), and introduced the Chinese kyŏng-myo measurements from Pan'gyesurok, written by Yu Hyŏngwŏn. Kim Hyŏnggŭn, trans., 2015, "Chijeŭi," Kündae Han'guk ŭi kaehyŏk kusang kwa Yu Kilchun (The road map for reform in modern Korea and Yu Kilchun), Koryŏ Taehakkyo Ch'ulp'an Munhwawŏn, 376-378. 
household tax; and hyang taxes should consist of supplementary land tax, supplementary business tax, and supplementary income tax.

As suggested by the names of chu tax and hyang tax, each of local taxes was levied as a surtax on national taxes. Specifically, added land tax was to be "from 15 pun to 20 pun of the national tax," while added business tax was to be "from 7 pun to 15 pun of the national tax." 23 This meant the amount of added land tax could be set from 15 to 20 percent of the national land tax, and added business tax from 7 to 15 percent of the national business tax. Similarly, hyang taxes were to be "from 10 pun to 20 pun" regardless of the tax category, which meant that the supplementary land tax and supplementary business tax could be set from 10 to 20 percent of added land tax and added business tax, respectively. ${ }^{24}$

Table 1. Yu Kilchun's Concept of National Taxes, Chu Taxes, and Hyang Taxes in "Semubu"

\begin{tabular}{l|l|l}
\hline \multicolumn{1}{c|}{ Tax } & \multicolumn{1}{c|}{ Category } & \multicolumn{1}{c}{ Calculation } \\
\hline \multirow{2}{*}{$\begin{array}{l}\text { National taxes } \\
\text { 國税 }\end{array}$} & Land tax & \\
\cline { 2 - 3 } & Business tax & \\
\cline { 2 - 3 } & Income tax & \\
\hline \multirow{4}{*}{$\begin{array}{l}\text { Chu taxes } \\
\text { 稅 }\end{array}$} & Added land tax & $\begin{array}{l}\text { From 15 to 20 per- } \\
\text { cent of the land tax }\end{array}$ \\
\cline { 2 - 3 } & Added business tax & $\begin{array}{l}\text { From 7 to 10 percent } \\
\text { of business tax }\end{array}$ \\
\cline { 2 - 3 } & Household tax & $\begin{array}{l}\text { From 10 to 20 per- } \\
\text { cent of added land } \\
\text { tax }\end{array}$ \\
\hline \multirow{4}{*}{$\begin{array}{l}\text { Hyang taxes } \\
\text { 鄉稅 }\end{array}$} & $\begin{array}{l}\text { Supplementary land } \\
\text { tax }\end{array}$ & $\begin{array}{l}\text { From 10 to 20 per- } \\
\text { cent of added busi- } \\
\text { ness tax }\end{array}$ \\
\cline { 2 - 3 } & $\begin{array}{l}\text { Supplementary } \\
\text { business tax }\end{array}$ & $\begin{array}{l}\text { Supplementary } \\
\text { income tax }\end{array}$ \\
\cline { 2 - 3 } & \multicolumn{2}{|}{} \\
\hline
\end{tabular}

23 Yu Kilchun, "Semubu," 32.

24 Ibid., 51. 
Exploitation occurred in the tax collection system where local magistrates and the isŏ class were in charge of collecting taxes, mainly because of the lack of finances in local governments and because the isŏ class did not receive official pay from the government before the Kabo Reforms. Moreover, all the expenses required for tax collection needed to be raised by local government offices.

The members the Enlightenment Party (kaehwap'a) had designed a plan to introduce a local tax system, but it was not implemented in reality. ${ }^{25}$ Instead, part of the land and poll tax was designated as expenses for kun, but it was not enough to cover the demands of all local government offices, and most of it was used to pay wages to government office employees. ${ }^{26}$ Moreover, local governments had to send finances to the central government, which further reduced their own revenue, and the burden of a lack of finances for local governments was shifted to the general public, who were inevitably exploited in the process of tax collection. ${ }^{27}$ Therefore the implementation of local taxes was meaningful in that they were separate from national taxes and legally guaranteed stable finances for local governments. ${ }^{28}$

$\mathrm{Yu}$ Kilchun seems to have planned to collect local taxes as surtax on national tax because he could not find different sources of taxation for local taxes. Since local taxes were to be charged as surtaxes, it would

25 Kim, T’aeung, 1991, “1894-1910 nyŏn chibang seje ŭi sihaeng kwa ilje ŭi chose sut'al" (Implementation of a local tax system and the Japanese tax exploitation from 1894-1910). Han'guksaron 26, 101-109.

26 Ibid., 109-118; Yu Chŏnghyŏn, "1894-1904 nyŏn chibang chaejŏng chedo," 103.

27 Yu Chŏnghyŏn, "1894-1904 nyŏn chibang chaejŏng chedo," 104-114.

28 Local taxes were first implemented in Korea through the "Local Tax Regulations (chibangse kyuch'ik)" in 1907. Following the failure of these regulations, local taxes were implemented again through the "Local Expenditure Law (chibangbibŏp)" in 1909 (Kim, T'aeung, 1991, "1894-1910 nyŏn chibang seje," 125). Considering that the purpose of the implementation of local taxes was to raise funds for the Japanese Residency-General of Korea's colonization project, Yu Kilchun's concept of local taxes is significant. 
have been greatly influenced by the fluctuations in national taxes.

Fundamentally, however, it was very likely for the taxpayers to understand local taxes as an increase in national taxes, even more so because local taxes were to be levied as surtaxes. As a result, the establishment of local taxes was likely to see resistance. ${ }^{29}$

The resistance against taxation caused by the implementation of local taxes was to be resolved through the creation of local assemblies. Yu Kilchun conceived the implementation of local taxes along with the establishment of local assemblies_chuhoe and hyanghoe.

Chu taxes are levied for the administrative management of each chu. Residents of each $c h u$ are responsible for $c h u$ taxes. Therefore, $c h u$ taxes are designed to serve a specific purpose and separated from national taxes. If the tasks of imposing and collecting chu taxes are delegated to provincial governors, and the problems of exploitation surface, there is no way to eliminate the problems. To prevent exploitation, chuhoe are established, and members of chuhoe are elected according to the election law from among the residents of each kun within the chu. Every winter, the members of chuhoe gather at the $c h u$ office to discuss and set the annual budget and expenses for the next year. The members decide on the amount of $c h u$ taxes to be levied, depending on the level of the burden of administrative tasks involved. The budget proposal should be prepared and submitted by the governor of the $c h u$ to the members of the chuhoe, who will then make the decisions. The members of chuhoe review the proposal and add or remove necessary provi-

29 After the failure of the Local Tax Regulations in 1907, the Japanese ResidencyGeneral of Korea tried to avoid the term "local tax" when enacting the Local Expenditure Law in 1909. The reason was that "using the term local tax could aggravate the people as if a new tax is being imposed on them." Hansŏngbu samugwan küp kak to sŏgigwan hoeüi yorok (Records of the meetings of Seoul governor and provincial secretaries). Re-cited from Kim T'aeung, 1991, “1894-1910 nyŏn chibang seje," 135. 
sions. However, any changes can be made only after majority consent of the members of chuhoe, assuring that a shortage of expenses does not occur... ${ }^{30}$

Hyang taxes are levied for the administrative management of each hyang... The amount of taxes should be more than one tenth and no more than one twentieth of Kun taxes. In special circumstances, members of hyanghoe may decide without bias to propose a larger budget, but it cannot be implemented without the authorization of the ministers of internal affairs and finance. Also, the budget for ordinary tax revenue and expenditure need to be determined by the hyanghoe and authorized by kun'gam (county magistrates)... ${ }^{31}$

Chuhoe was given the authority to elect members of the assembly through elections, deliberate and adjust the annual budget proposal prepared by the state governor, and set the amount of tax to be levied. Less information is available on hyanghoe, but hyanghoe had the authority to deliberate on the budget of ordinary tax revenues and expenditures.

In the Deliberative Council's concept of hyanghoe from 1894, only the authority to impose taxes was assigned to myŏnhoe, but Yu's "Semubu" assigned the superior authority to deliberate on the budget to chuhoe and hyanghoe. This idea of guaranteeing the right to deliberate on the budget, which contributed to the development of modern parliamentary system, to chuhoe and hyanghoe was groundbreaking at the time. It was a measure to not only eliminate exploitation and similar practices carried out by local magistrates and the isŏ class in the process of tax collection but also to fundamentally resolve the medieval governing system.

30 Yu Kilchun, "Semubu," 31.

31 Ibid., 51. 


\section{Tax Collection System Reform}

$\mathrm{Yu}$ Kilchun also devised a different concept for the imposition and collection of taxes. The Deliberative Council assigned the right to impose taxes to hyanghoe to eliminate local magistrates and the iso class from the process of taxation, but in "Semubu" $\mathrm{Yu}$ assigned this right to hyanggam (district superintendent).

Since tax source review and taxable amounts are determined in the budget plan, hyanghoe is solely responsible for gathering and collecting taxes. However, reviewing tax information is not possible without hyanghoe. As for the land tax, real estate ledgers are kept at the hyang-level; for business tax, the register of operating businesses are also kept at the hyang-level; income tax and other fundamental information for taxes are basically kept at the hyanglevel. Therefore, it is impossible not to consider hyang as the base unit of local government administration... ${ }^{32}$

The government ordinance to assign kun'gam the responsibility to collect taxes by themselves all year long cannot be done in reality. Therefore, currently, a large number of the members of the iso class and military officers are dispatched to hyang and $r i$ and cause disturbances. Therefore, in this system, hyanggam and hyangsegam (district tax officers) are assigned to the duties of managing taxes of one hyang each and carry out the order of superior authorities. This creates three benefits. The first is the elimination of evil practices, such as tax imposition without cause, omission of taxpayers, double taxation, deception, and tax evasion. Second, it can get rid of the evil practices of the iso class, military officers, and local magistrates, who inculpated innocent people and robbed them of their properties. Third, hyanggam and hyangsegam are constantly aware

32 Ibid., 7-8. 
of the circumstances in the hyang. Therefore, they can collect taxes within a certain period after figuring out the economic situation of the hyang. This would help reduce the number of people who postpone or fail to pay taxes... ${ }^{33}$

Hyanggam were government officials who were in charge of hyang, an administrative divisional unit with governmental authority, with the change of the administrative divisional system into the chu-kun-hyang-ri system. With the assembly given the right to deliberate on the budget, all other administrative activities, such as tax source review, taxation, tax collection and payment, were assigned to officials at the hyang-level. $\mathrm{Yu}$ believed that this would eliminate evil practices carried out by the isŏ class and also reduce late or delayed tax payments as hyanggam would have a better understanding of the territory under his jurisdiction than kun'gam (county magistrate), who were in charge of overseeing a higherlevel and bigger region.

Yun conceived and proposed a relatively specific process of taxation, tax collection and payment through hyang, which can be summarized as follows:

1. As for national taxes, the head of a (kun) tax office delivers the list of taxes, which contains a specific tax amount for each category, to the hyanggam.

(For chu taxes, kun'gam delivers the list of taxes to hyanggam.)

2. The hyanggam reviews the content of the list of taxes and compares it with the register of land taxes and register of operating businesses.

When there are differences, the hyanggam compares the list of taxes with sources from city tax offices and county offices to correct the differences.

3. The hyanggam records the content of the list of taxes accordingly: land tax information should be recorded in the periodical land tax

33 Ibid., 25-26. 
ledger, and business tax should be recorded in the periodical business tax ledger.

4. The hyanggam issues a tax invoice, which contains the tax type and amount to be paid, to the residents (taxpayers) of hyang.

5. The taxpayer pays the taxes to the district tax office by the due date.

6. The tax officer notifies the hyanggam of the receipt of tax payments.

7. The hyanggam records the date of the receipt of tax payments in the periodical ledger, stamps half a stamp each on the paid tax amount recorded in the periodical ledger and the tax invoice. The hyanggam also stamps a seal in the center of the tax invoice and returns the tax payment register to the tax officer.

8. The tax officer also stamps a seal on the periodical tax ledger, halves the tax invoice, keeps one half in the district tax office and issues the other half to the taxpayer.

Tax was to be handled at the hyang level once the list of taxes was delivered from kun to hyang. And the government office at the hyang level was to be in charge of managing the tax roll, which lists the types of taxes and can be used as a resource for determining tax amounts aside from the list of taxes, periodical ledgers by category of taxation, which contains the tax amounts and tax payers at the hyang level, and the tax invoice by category of taxation, which is issued to the taxpayers. The officials in charge of taxation at the hyang level were hyanggam and hyangsegam, and all taxes were to be paid at the district tax office. This shows that Yu Kilchun thought to work on specializing tax work by establishing official positions and institutions for the handling of taxes and storing of related documents at the hyang level.

Under this structure, the authority of counties in tax related matterstax source review, taxation, and tax collection-was taken away from the kun and given to the hyang. In this way, Yu's concept of the tax system in "Semubu" was a measure to eliminate the local magistrates and the iso class, which had caused problems of exploitation of the taxpayers, in the process of tax collection. 
Then, would there be no possibility of such exploitation cause by local magistrates and the isŏ class recurring at the hyang level? Considering that government officials would be able to scrutinize the local people's situations since the hyang was a smaller governing unit than the kun, and that excessive taxation can be prevented in advance by the local assemblies which had the power to deliberate the budgets and fix the tax amounts, there was a low possibility of such exploitation happening in the new system. Moreover, as local taxes were to be established solely to cover the expenses of regional governments, the possibility of imposing exorbitant tax was definitely lower than before.

In sum, Yu Kilchun designed a tax system, in which tax administration was conducted at the hyang level, a sub-unit of kun. In this aspect, his concept of the reorganization of administrative divisions was ultimately focused on changing myŏn, a non-governing administrative unit, to hyang, a governing administrative unit. And his argument for the establishment of local taxes was also centered on stabilizing the foundation of the operation of hyang by providing independent finances to cover government expenditures. On such a basis, $\mathrm{Yu}$ wanted the hyang to take responsibility for tax service and administration to conduct close and detailed tax collection activities. This was a concept that could secure stable national finances and reduce the authority of the local magistrates and the iso class, who had been dispersed throughout the kun. 
Figure 5. An Example of the "List of Taxes"34

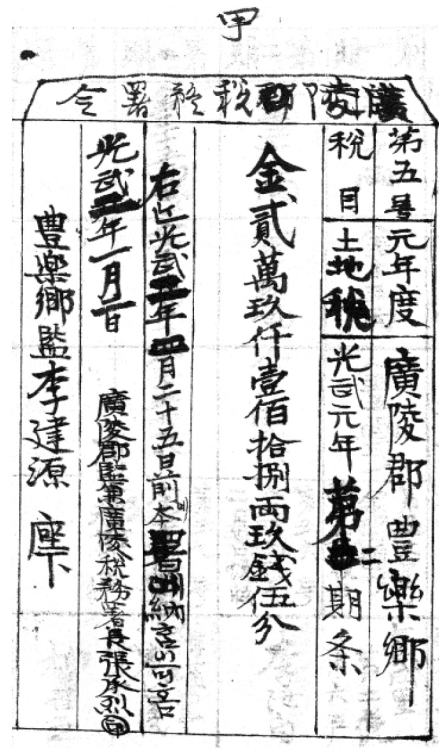

\begin{tabular}{|c|c|c|c|c|c|}
\hline \multicolumn{6}{|l|}{ Kap } \\
\hline \multicolumn{6}{|c|}{ Notice from Kwangnŭng-gun Tax Office } \\
\hline \multirow[t]{3}{*}{$\begin{array}{l}\text { To Superintendent } \\
\text { of } \\
\text { P'ungnak-hyang } \\
\text { Yi Kŏnwŏn }\end{array}$} & \multirow{3}{*}{$\begin{array}{l}\text { January 2, } \\
\text { Kwangmu } 2 \\
\text { Magistratc } \\
\text { of } \\
\text { Kwangnŭng } \\
\text {-gun and the } \\
\text { Head of the } \\
\text { Kwangnŭng } \\
\text {-gun Tax } \\
\text { Office } \\
\text { Chang } \\
\text { Sŭngryŏl } \\
\text { Seal }\end{array}$} & \multirow{3}{*}{$\begin{array}{l}\text { The tax on } \\
\text { the right } \\
\text { page must } \\
\text { be paid to } \\
\text { this tax } \\
\text { office of } \\
\text { the } \\
\text { taxpayer's } \\
\text { hyang by } \\
\text { April } 25 \text {, } \\
\text { Kwangmu } \\
2\end{array}$} & \multirow{3}{*}{$\begin{array}{l}\text { Cash } \\
29,118 \\
\text { nyang } \\
9 \text { chŏn } \\
5 \text { p'un }\end{array}$} & Tax Type & No. 5 \\
\hline & & & & Land Tax & $\begin{array}{l}\text { Korean Calendar } \\
\text { Year }\end{array}$ \\
\hline & & & & $\begin{array}{l}\text { Kwangmu } \\
1 \text {, Period } 2\end{array}$ & $\begin{array}{l}\text { P'ungnak-hyang, } \\
\text { Kwangnǔng-gun }\end{array}$ \\
\hline
\end{tabular}

34 A "List of Taxes" containing information on land tax, a type of national tax. The head of the kun tax office issues a "List of Taxes" containing records of land taxes that a hyang must pay to hyanggam. Then hyanggam compares the List of Taxes to the hyang's register of land taxes to make corrections and adjustments. Based on the amount of taxes listed in the tax statement, hyanggam issues a tax invoice to each taxpayer. 
Figure 6. An Example of a "Periodical Ledger"35

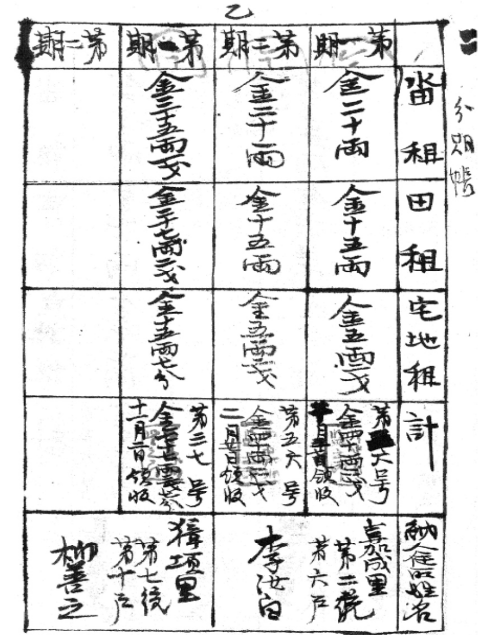

\begin{tabular}{|c|c|c|c|c|c|}
\hline \multicolumn{5}{|l|}{ Ǔl } & \multirow{7}{*}{$\begin{array}{l}\text { Periodical } \\
\text { Register }\end{array}$} \\
\hline Period 2 & Period 1 & Period 2 & Period 1 & & \\
\hline & $\begin{array}{l}\text { Cash } \\
35 \text { nyang } \\
1 \text { chŏn }\end{array}$ & $\begin{array}{l}\text { Cash } \\
21 \text { nyang }\end{array}$ & $\begin{array}{l}\text { Cash } \\
20 \text { nyang }\end{array}$ & Rice paddy tax & \\
\hline & $\begin{array}{l}\text { Cash } \\
27 \text { nyang } \\
2 \text { chŏn }\end{array}$ & $\begin{array}{l}\text { Cash } \\
15 \text { nyang }\end{array}$ & $\begin{array}{l}\text { Cash } \\
15 \text { nyang }\end{array}$ & Field tax & \\
\hline & $\begin{array}{l}\text { Cash } \\
15 \text { nyang } \\
7 \text { p'un }\end{array}$ & $\begin{array}{l}\text { Cash } \\
5 \text { nyang } \\
2 \text { chŏn }\end{array}$ & $\begin{array}{l}\text { Cash } \\
5 \text { nyang } \\
2 \text { chŏn }\end{array}$ & Residential lot tax & \\
\hline & $\begin{array}{l}\text { No. } 37 \\
\text { Cash } 77 \text { nyang } 2 \\
\text { chŏn } 7 \text { p'un } \\
\text { Received } \\
\text { November } 2 \\
\end{array}$ & $\begin{array}{l}\text { No. } 56 \\
\text { Cash } 40 \text { nyang } 2 \\
\text { chŏn } \\
\text { Received } \\
\text { February } 27 \\
\end{array}$ & $\begin{array}{l}\text { No. } 26 \\
\text { Cash } 40 \text { nyang } 2 \\
\text { chŏn } \\
\text { Received February } \\
27\end{array}$ & Total & \\
\hline \multicolumn{2}{|c|}{$\begin{array}{l}\text { Ryu Sŏnji } \\
\text { Changhang-ri, T'ong No. 7, } \\
\text { House No. } 10\end{array}$} & \multicolumn{2}{|c|}{$\begin{array}{l}\text { Yi Yŏbaek } \\
\text { Kasŏng-ri, T’ong No. 2, House No. } 6\end{array}$} & $\begin{array}{l}\text { Taxpayer } \\
\text { Taxpayer } \\
\text { Name }\end{array}$ & \\
\hline
\end{tabular}

35 The "Periodical Ledger" of land tax, a type of national tax. A hyanggam receives land tax statements from the county tax office, checks the amount of taxes that the hyang must pay, and records the amount of land tax that each taxpayer must pay in the periodical ledger. When the taxpayers of a hyang pay their taxes, the hyanggam records the date tax was paid and stamps a seal across the pages of the periodical ledger and the tax invoice. In order to "extend the power of the people," Yu Kilchun proposed the division of tax payment period into two. The first period for land tax payment is from July 1 to December 30, and the second from January 1 to June 30; the first period for business tax payment is from January 1 to June 30, and the second from July 1 to December 30. 
Figure 7. An Example of Tax Invoice ${ }^{36}$

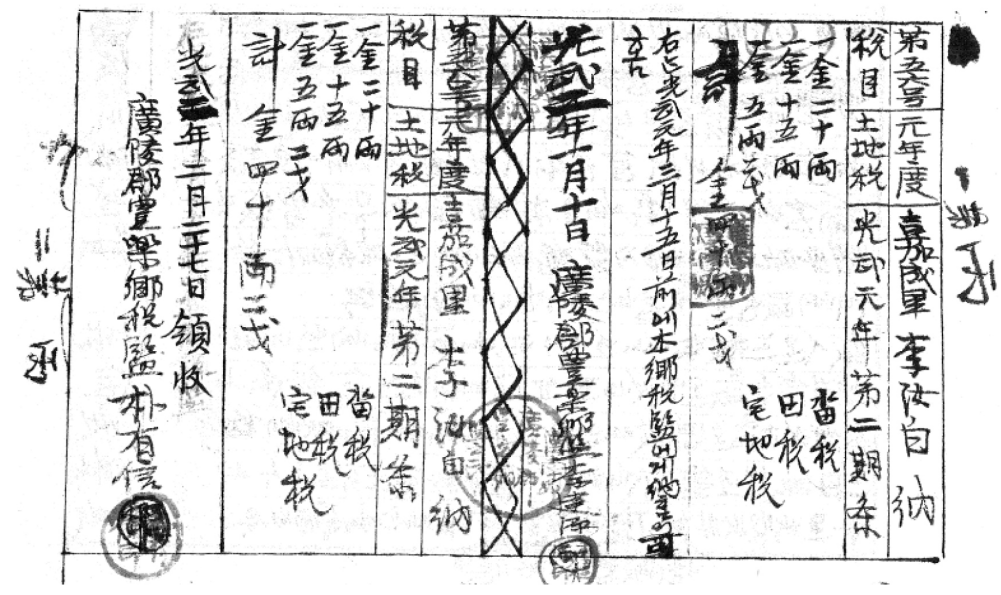

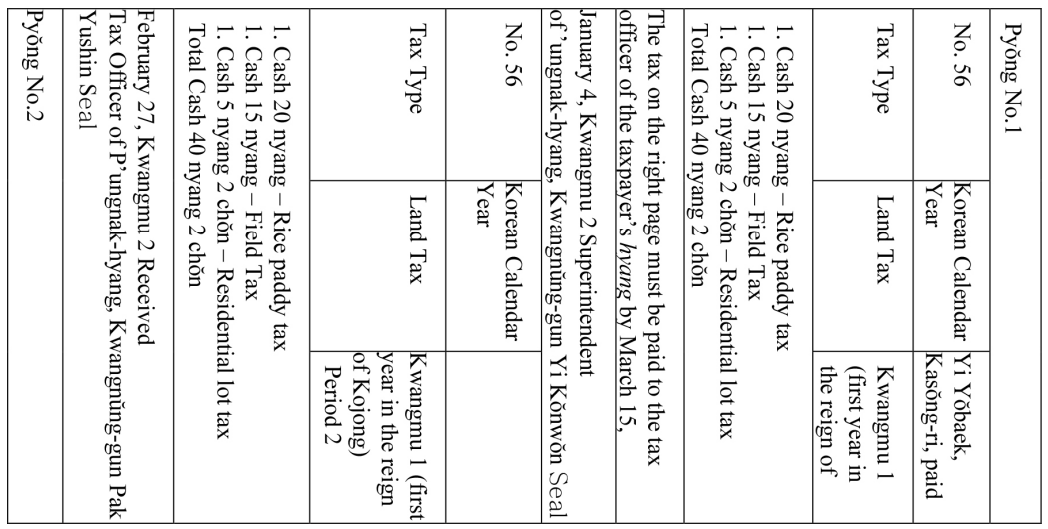

36 A tax invoice for land tax, a type of national taxes, is issued to each taxpayer by hyanggam. When the taxpayer pays the tax, hyangsegam stamps his seal on the tax invoice "Pyŏng No. 2" to notify the hyanggam of the receipt of tax payment. Hyanggam then stamps a seal across the "Periodical Ledger" and the tax invoice so that each is marked with half a seal; as well as across the pages of the tax invoice numbered "Pyŏng No. 1" and "Pyŏng No. 2." The tax invoice is then returned to the hyangsegam. Hyangsegam then files the page "Pyŏng No. 1" at the tax office and returns the page "Pyŏng No. 2" to the taxpayer. 


\section{Conclusion}

"Semubu," a document housed at the Korea University Museum, is assumed to be a document authored by Yu Kilchun during his exile in Japan during Emperor Kojong's reign in the Korean Empire. It criticizes the changes in the tax system, in which the authority to impose and collect taxes had been taken away from the local magistrates and the iso class during the Kabo Reforms but was once again returned to them.

Specifically, Yu Kilchun devised a concept of tax system reform on the premise of the reorganization of the administrative districts into the chukun-hyang-ri system. This idea was similar to the regional system reforms from 1895 and 1896, when provincial-level administrative divisions were reorganized and smaller-level divisions were unified into kun. Yu's idea of naming the provincial-level administrative divisions "chu," which was taken from the ancient Chinese system, and renaming kun to hyang was similar to Yu Hyŏngwŏn's concept of the hyang-ri system, in that both wanted to make myŏn (hyang) a governing administrative unit, placed under direct government control.

To fund the operation of local governments, Yu proposed to create local taxes, chu taxes and hyang taxes, separate from national taxes, and these taxes were to be levied as surtaxes on the national taxes. Yu also hoped to establish chuhoe and hyanghoe, which were regional assemblies with the authority to deliberate on the budget. The authority to review tax sources, levy and collect taxes was given to the hyang, a small unit of administrative division that was to become a new governing unit.

This was a change from the previous system, in which the authority to review tax sources, levy and collect taxes belonged to the kun. By imbuing this authority to the hyang, Yu Kilchun planned to remove local magistrates and the iso class from the tax collection process. Yu's concept of the tax system definitely was designed to reduce exploitation of the taxpayers: the hyang was a smaller unit than the kun and therefore its administration could interact with its residents more closely; a local assembly was to be established to be in charge of deliberating on the budget and 
determining the tax amounts; local taxes were also to be instituted as a separate financial source for the operation of hyang-level government offices.

$\mathrm{Yu}$ Kilchun's writings on finances and the tax system that have been explored in previous studies mostly originated from before the Kabo Reforms. In terms of content, these documents mainly proposed land tax reform, and the central government's tax system reform. Since the "Semubu" discusses the reorganization of administrative divisions and local tax administration, as well as local tax system reform, the discovery of this text is significant, as it expands the range of the reform ideas proposed by $\mathrm{Yu}$ Kilchun, and furthermore the Enlightenment Party.

\section{References}

1. Yu, Kilchun. "Semubu" (Tax Department), Korea University Museum.

2. . 1895. Sŏyu kyŏnmun. Kyosunsa (Kyŏngin Munhwasa, 1969, photographic edition).

3. Han'guk yŏksa chimyŏng sajŏn p'yŏnch'an wiwŏnhoe. 2008. Han'guk yŏksa chimyŏng sajŏn (Dictionary of Place Names in Korean History). Yŏgang Ch'ulp'ansa.

4. Kim, Yongsŏp. 1974. “Kapsin, Kabo kaehyŏkki kaehwap'a ŭi nongŏmnon" (The theory of agriculture of the Enlightenment Party during the Kapsin and Kabo Reforms period). Tongbang Hakji (The Journal of Korean Studies) 15.

5. _ _ 1988. "Kŭndaehwa kwajŏng esǒŭi nongŏp kaehyŏk ŭi tu panghyang" (Two directions of the agricultural reform in the process of modernizations). Han'guk chabonjuŭi sŏnggyŏk nonjaeng (Debate on the nature of Korean capitalism). Taewangsa.

6. Kim, T’aeung. 1991. “1894-1910 nyŏn chibang seje ŭi sihaeng kwa ilje ŭi chose sut'al" (Implementation of a local tax system and the Japanese tax exploitation from 1894-1910). Han'guksaron 26. 
7. . 1997. "Kŭndae Chungguk, Ilbon ŭi chibang chach'iron kwa Hanmal ŭi chibang chach'i munje" (The theory of local autonomy in modern China and Japan and the issue of modern autonomy in the late Korean Empire period). Yǒksa Kyoyuk 64.

8. Yang, Jinah. 2014. "Kapsin chŏngbyŏn ihu Yu Kilchun ŭi chajŏng kaehyŏngnon" (Yu Kilchun's financial reform theory after the Kapsin Coup). Han'guksa Hakbo 57.

9. O, Yŏnggyo. 1994. "Pan'gye Yu Hyŏngwŏn ŭi chibangjedo kaehyŏngnon yŏn'gu” (Study on Pan'gye Yu Hyŏngwŏn's theory of local government system reform). Kuksagwan Nonch'ong 57.

10. Wang, Hyŏnjong. 1997. "19 segi huban chisejedo kaehyŏngnon kwa Kabo kaehyŏk" (Theory of local tax system reform and the Kabo Reform in the late nineteenth century). Han'guk kŭnhyŏndae ŭi minjok munje wa shingukga kŏnsŏl (National problems in modern and contemporary Korea and the founding of a new nation). Kim Yongsŏp Kyosu Chŏngnyŏn Kinyŏm Han'guk Sahangnon Ch'ong Kanhaeng Wiwŏnhoe. Chisik Sanŏpsa.

11. Yu, Chŏnghyŏn. 1992. "1894-1904 nyŏn chibang chaejŏngjedo ŭi kaehyŏk kwa isŏch'ŭng tonghyang”' (The trend of local financial system reform and the isŏ class during 1894-1904). Chindan Hakbo 73.

12. Yun, Chŏngae. 1985. "Hanmal chibangjedo kaehyŏk ŭi yŏn'gu" (Study on the local government system reform in the late Korean Empire period). Yǒksas Hakbo 105.

13. Yi, Sangch'an. 1986. “1906-1910 nyŏn ŭi chibang haengjŏngjedo ŭi pyŏnhwa wa chibang chach'i nonŭi”" (Changes in the local administrative system and a discussion on local autonomy during 19061910). Han'guk Hakbo 42.

14. _ 1989. "1894-5 nyŏn chibangjedo kaehyŏk ŭi panghyang: hyanghoe ŭi pŏpjehwa sido rŭl chungsimŭro" (Direction of local government system reform during 1894-1895: Focusing on the attempt to legalize hyanghoe). Chindan Hakbo 67.

15. Cho, Chŏnghŭi. 2006. "Yu Kilchun ŭi kyŏngje kaehyŏngnon" (Yu Kilchun's theory of economic reform). Han'guk Sasanggwa 
Munhwa (Korean Thought and Culture) 33.

16. Chŏng, Ch'angryŏl. 1982. "Hanmal pyŏnhyŏk undong ŭi chŏngch'i, kyŏngjejŏk sŏnggyŏk" (The political and economic nature of the reform movement in the late Korean Empire period). Han'guk minjokjuŭinon (Theory of Korean nationalism). Ch'angjakgwa Pip'yŏngsa. 


\section{Yu Kilchun's Concept of Reform of the Tax System in the Korean Empire}

Yang Jinah

$\mathrm{Yu}$ Kilchun in "Semubu (Tax Department)" criticizes the trend of the tax system, in which the authority to impose and collect taxes had been taken away from the local magistrates and the isŏ class (composed of hyangni, local functionaries, and sŏri, petty clerks) during the Kabo Reform was once again returned to them.

$\mathrm{Yu}$ Kilchun devised a concept of tax system reform on the premise of the reorganization of the administrative districts into the chu-kun-hyang-ri (state-countydistrict-village) system. Yu's idea was to make myŏn (hyang, district) a governing administrative unit, placed under direct government control.

To fund the operation of local governments, $\mathrm{Yu}$ proposed to create local taxes, chu taxes and hyang. Tax amounts were to be determined by local assemblies, chuhoe and hyanghoe, which were given the authority to deliberate on budget. The authority to review tax sources, levy and collect taxes was given to hyang, a small unit of administrative division. By imbuing this authority to hyang, $\mathrm{Yu}$ Kilchun planned to exclude local magistrates and the isŏ class in the tax collection process.

Since "Semubu" discusses the reorganization of administrative divisions and local tax administration, as well as local tax system reform, the discovery of this text is significant, as it expands the range of the reform ideas proposed by $\mathrm{Yu}$ Kilchun, and furthermore the Enlightenment Party.

Keywords: Yu Kilchun, Semubu (稅務部), local taxes, local autonomy, hyanghoe (㰾會) 


\section{$<$ 국문초록>}

\section{대한제국기 유길준의 세제개혁 구상}

양진아 (고려대학교 한국사학과 박사과정)

고려대학교 박물관 소장「稅務部」는 유길준이 일본망명시절인 대한제국기 고종 재위 기간에 작성한 문서로 추측된다. 갑오개혁기 수령·이서층으로부터 분리되었 던 징세업무가 다시 수령과 이서층의 소관으로 복귀한 대한제국기 복고적 세무 양상을 비판하는 성격의 문서이다.

유길준은「稅務部」에서 州·郡·鄉·里制로의 개편을 전제로 한 세제개혁을 구상하 였다. 面을 鄉으로 개편하려 한 구상은 面(鄉)을 관치 영역으로 편입하려 한 것이 라는 점에서 유형원의 鄉里制 구상과 유사했다.

국세와는 별도의 지방관청 재원으로 지방세인 州稅와 鄉稅를 설치하고자 하였 고, 國稅에 附加하는 방식으로 稅額을 산출하고자 하였다. 과세액은 예산심의 권 한을 부여받은 지방의회 州會와 鄉會를 통해 결정하고자 하였다. 세원의 조사와 조세부과·징수·수납의 총괄적 세무 행정권한은 새롭게 관치 행정구역으로 편입된 鄉에 부여되었다.

이는 기존에 郡이 담당한 세원 조사, 조세부과·징수 권한을 鄉에 부여한 것으로 기존 조세수취과정에서 문제가 되었던 수령·이서층을 완전히 배제하려 한 구상이 었다.

기존 연구에서 활용해온 유길준의 재정, 세제 관련 저작들은 시기적으로는 갑오 개혁 이전, 내용적으로는 토지제도개혁론, 중앙의 조세제도개혁론에 관한 것들이 대부분이었다.「稅務部」에서 지방행정구역과 지방세무의 개편을 비롯한 地方稅制 개혁을 기술하여 유길준, 나아가 개화파 개혁 구상의 범위를 확장시키고 있다는 점에서「稅務部」발굴의 의미를 찾을 수 있다.

주제어: 유길준, 세무부(稅務部), 지방세(地方稅), 지방자치, 향회(鄉會) 